\title{
Kasvibiomassan laadullinen soveltuvuus bioenergian raaka-aineeksi
}

\author{
Arja Santanen, Epie Kenedy, Pirjo Mäkelä, Frederick Stoddard \\ Maataloustieteiden laitos, Latokartanonkaari 5-7, 00014 Helsingin yliopisto, etunimi.sukunimi@ helsinki.fi
}

Eri bioenergiantuottotavat asettavat kasvibiomassalle erilaisia vaatimuksia. Biologiset, käymiseen perustuvat menetelmät käyttävät liukoisia sokereita ja tärkkelystä lähteinään. Näissä menetelmissä biomassan epäorgaanisia yhdisteitä sisältävä jäänne voidaan hyödyntää rehuna ja lannoitteina, ja biomassan kosteuspitoisuus aiheuttaa ongelmia vain satoa varastoitaessa. Termokemiallisia menetelmiä käytettäessä sen sijaan kosteuden haihduttamiseen kuluu energiaa ja biomassan sisältämät alkuaineet voivat vaikuttaa prosessissa muodostuvan tuhkan ominaisuuksiin. Kertyvä kuona hidastaa laitteiston lämmönsiirtokykyä ja syövyttää putkia. Erityisesti korkeat pii- ja alkalimetallipitoisuudet $(\mathrm{K}$ ja $\mathrm{Na})$ ja korkea klooripitoisuus $(\mathrm{Cl})$ lisäävät polttolaitteiston ylläpitokustannuksia.

Olemme Helsingin yliopiston Soveltavan biologian laitoksella selvittäneet eri kasvien sopivuutta bioenergian raaka-aineeksi määrittämällä biomassatuotannon lisäksi kasvibiomassasta tuhka-, hiili-, typpi-, sekä alkuainepitoisuudet. Kasvibiomassan hiili- ja typpipitoisuudet ovat olleet kasvilajista riippumatta yleensä $41-45 \% \quad(\mathrm{C})$ ja $0,6-3 \quad \% \quad(\mathrm{~N})$ kuiva-aineesta. Tässä raportissa kerromme bioenergiatarkoitukseen kasvatettujen kuitu- ja öljyhampun, sekä rehumaissin analyysituloksista. Näiden lisäksi tulemme tekemään analyysejä myös maa-artisokan versoista ja mukuloista, sekä valkolupiinin versoista. Tulostemme mukaan hiilen määrä on tasaisesti jakautunut maissin maanpäällisissä osissa tyvestä latvaan, kun taas typen ja fosforin $(\mathrm{P})$ määrät ovat korkeammat kehittyvissä tähkissä ja verson latvuksessa. Kloorin $(\mathrm{Cl})$ ja kaliumin $(\mathrm{K})$ pitoisuudet puolestaan vähenivät jyrkästi kohti latvusta. Maissin $\mathrm{K}-$ ja $\mathrm{Cl}$ pitoisuudet olivat yli kaksinkertaiset hampun K- ja Cl-pitoisuuksiin verrattuna. Öljyhamppu puolestaan sisälsi noin 5-kertaisen määrän kalsiumia $\mathrm{Ca}$ verrattuna maissiin. Öljyhampun ja kuituhampun alkuainepitoisuudet poikkesivat myös suuresti. Useimpien alkuaineiden pitoisuudet olivat kuituhampussa matalampia kuin öljyhampussa.

Avainsanat: Alkuainepitoisuus, biomassa, bioenergia, ICP, hamppu, maissi 


\section{Johdanto}

Bioenergiakasvin hyviä ominaisuuksia ovat korkea biomassantuotanto, vähäinen lannoitteiden ja torjuntaaineiden tarve, matala tuhkapitoisuus, sekä bioenergian tuotantomenetelmästä riippuen sopiva alkuaineiden määrä biomassassa. Alkalimetallit kalium $(\mathrm{K})$ ja natrium $(\mathrm{Na})$, sekä epämetalleista pii $(\mathrm{Si})$, kloori $(\mathrm{Cl})$ ja rikki (S) ovat ongelmallisia erityisesti lämpökemiallisissa reaktioissa sillä ne vahingoittavat laitteistoja saostumalla ja aiheuttamalla korroosiota (Jenkins ym. 1998). Toisaalta anaerobisessa lignoselluloosan hajotuksessa tarvitaan ravinteita ylläpitämään mikrobien kasvua ja tiettyjä metalleja entsyymiaktivaattoreiksi (Aresta ym. 2003). Liian korkeat alkuainepitoisuudet saattavat kuitenkin häiritä myös tätä prosessia (Urban ym. 2008).

Eri kasvilajien ja lajikkeiden alkuainepitoisuudet voivat poiketa toisistaan suuresti. Lisäksi lannoitteiden käyttö, maaperän ominaisuudet, sekä sadonkorjuun ajankohta vaikuttavat kasvibiomassan sisältämien hiilen, typen ja alkuaineiden määriin (El-Nashaar ym. 2009). Esimerkiksi piin määrä kasvibiomassassa saattaa vaihdella suuresti (jopa 10x) kasvualustasta, kehitysasteesta ja lajista tai lajikkeesta riippuen (Taber ym. 2002). Monivuotiset kasvit palauttavat verson sisältämät ravinteet talvehtivaan juurakkoon, mistä ne voidaan käyttää keväällä uuteen kasvuun. Tämän vuoksi monivuotiset kasvit eivät ole niin riippuvaisia maan lannoituksesta kuin yksivuotiset kasvit (Himken ym. 1997, Landstrom ym 1996).

Tarkoituksenamme on selvittää eri kasvien soveltuvuutta bioenergian tuotantoon vertaamalla niiden biomassojen kemiallista koostumusta ja sitä miten tämä koostumus muuttuu jos sato korjataan vasta kevättalvella, jolloin biomassan kuiva-ainepitoisuus on korkeampi ja alkuainepitoisuus mahdollisesti matalampi.

\section{Ainesto ja menetelmät}

Rehumaissia (KXA7211), kuituhamppua (USO) ja öljyhamppua (Finola) viljeltiin kesällä 2008 Viikin tutkimus- ja opetustilalla. Maissia lannoitettiin N-P-K 20:12:20 lannoitteella $120 \mathrm{~kg}$ N/ha ja hamppua $60 \mathrm{~kg}$ $\mathrm{N} /$ ha. Näytteet kerättiin neljältä $1 \mathrm{~m}^{2}$ rinnakkaisruudulta syyskuussa 2008 ja kevättalvella 2009 . Syyskuussa kerätyt maissit jaettiin neljään osaan, tyveen, keskiosaan, latvukseen ja tähkään. Tarkoituksena oli selvittää ravinteiden jakautuminen kasvissa tähkän täyttymishetkellä. Kevättalvella 2009 hamput leikattiin kolmeen osaan, i) $5 \mathrm{~cm}$ tyveltä, ii) sitä seuraava $5 \mathrm{~cm}$ ja iii) loppu kasvi. Maissin versot jaettiin samalla periaatteella, lisäksi tähkät kerättiin erikseen. Biomassamäärityksiä varteen näytteet kuivattiin +70-80C:ssa 2-3 vrk, punnittiin ja koko näyte-erä hienonnettiin oksasilppurilla, minkä jälkeen pieni erä silputtua kasvinäytettä jauhettiin $0.5 \mathrm{~mm}$ seulan läpi (Retsc ZM 200). Kuivasta jauhosta määritettiin tuhkapitoisuus tuhkaamalla näytteet muhveliuunissa $600^{\circ} \mathrm{C}$ :ssa $18 \mathrm{~h}$ (Nabertherm) ja hiili ja typpipitoisuudet Elementar vario MAX CNtyppianalysaattorilla (Elementar Analysensysteme $\mathrm{GmbH}$, Saksa). Kloori määritettiin uuttamalla noin $0.5 \mathrm{~g}$ näytettä mq-vedellä $+65^{\circ} \mathrm{C}$ :ssa ravistelulaitteessa ja mittaamalla klooripitoisuus uutteista titraukseen perustuvalla kloridometrillä (Chloride Analyzer 926, GWB). Al, Ca, Cu, Fe, K, Na, P, S, Si ja Zn analysoitiin hajottamalla kasvimassanäytteet (noin $250 \mathrm{mg}$ ) märkäpolttolaitteessa (MarsXpress, Hosmed Oy) $\mathrm{HNO}_{3}$ : ssa (69-70 \%, Baker Trace metal analysis-laatu) ja $\mathrm{H}_{2} \mathrm{O}_{2}$ :ssa. Suodatuksen jälkeen näytteistä analysoitiin alkuainepitoisuudet plasmaemissiospektrometria-tekniikalla (ICP-OES,Hosmed Oy) pitoisuusalueella $0.02-100 \mathrm{ppm}$.

\section{Tulokset ja tulosten tarkastelu}

Suurimmat erot koekasviemme maissin ja hampun alkuainekoostumuksessa olivat $\mathrm{K}$ ja Ca pitoisuuksissa. Maississa K pitoisuus vaihteli kasvin tyven noin $30 \mathrm{~g} / \mathrm{kg}$ kuiva-aineesta (KA) noin $11 \mathrm{~g} / \mathrm{kg} \mathrm{KA}$ latvuksessa. Sekä öljyhampun että kuituhampun K pitoisuudet olivat noin $12 \mathrm{~g} / \mathrm{kg} \mathrm{KA}$. Hampun biomassassa Ca pitoisuus oli puolestaan huomattavasti korkeampi, $>14 \mathrm{~g} / \mathrm{kg} \mathrm{KA}$ öljyhampussa ja kuituhampussa $>6 \mathrm{~g} / \mathrm{kg} \mathrm{KP}$ kun maississa Ca pitoisuus oli 2-3 g/kg KA kasvinosasta riippuen (Taulukko 1 ja 3). Maississa kasvin sisältämä $\mathrm{Ca}, \mathrm{Cl}$ ja $\mathrm{K}$ muodostavat gradientin, vähentyen tyveltä verson latvaan, kun taas $\mathrm{N}, \mathrm{P}$ ja $\mathrm{S}$ sijaitsevat kasvissa päinvastaisessa järjestyksessä. Fosforia $(\mathrm{P})$ on erityisen runsaasti kehittyvissä tähkissä, missä sitä kertyy fytaattina siemeniin. Magnesium (Mg), Fe ja Si ovat puolestaan kertyneet tasaisesti kasvin eri osiin (Taulukko 1). Kaliumin korkea pitoisuus maississa selittyy osittain varmaan lannoitteena annetun $\mathrm{K}$ korkeampana pitoisuutena pellossa. Sen sijaan kuituhamppu ja öljyhamppu saivat saman lannoituksen ja siitä 
huolimatta huomattavasti runsaamman biomassan kasvattanut kuituhamppu sisälsi vähemmän kaliumia kuin öljyhamppu (Taulukko 3).

Useiden alkuaineiden pitoisuudet olivat laskeneet huomattavasti keväällä korjatuissa maisseissa ja hampuissa, sen sijaan Al ja Fe pitoisuudet ovat poikkeuksellisesti lisääntyneet, joskaan tuloksia ei voi niiden osalta pitää merkitsevinä suurista keskihajonnoista johtuen (Taulukko 2 ja 4). Myös monivuotisessa ruokohelpissä $\mathrm{SiO}_{2}, \mathrm{Fe}, \mathrm{Cu}$ ja $\mathrm{Mn}$ pitoisuuksien on havaittu lisääntyvän keväällä korjatussa sadossa (Pahkala \& Pihala 2000). Tuhkapitoisuuden ja useiden alkuaineiden vähenemisestä huolimatta myöhäisemmän sadonkorjuun on havaittu vaikuttavan negatiivisesti metaanin tuottoon, johtuen liukoisen sokerin, rasvojen ja proteiinien osuuden vähenemisestä ja ligniinin sekä selluloosan osuuden lisääntymisestä vanhenevissa kasveissa (Prochow ym. 2005).

Taulukko 1. Alkuainepitoisuudet syyskuussa 2008 korjatun maissin (KXA 7211) eri osissa. Neljän rinnakkaisnäytteen keskiarvot \pm keskihajonta.

\begin{tabular}{ccccc} 
Alkuaine & Tyvi & Keskiosa & Latvus & Tähkä \\
\hline & & & & \\
$\mathrm{Al}$ & $23,48 \pm 16,47$ & $27,49 \pm 14,93$ & $28,49 \pm 11,42$ & $13,09 \pm 7,13$ \\
$\mathrm{Cu}$ & $6,67 \pm 1,80$ & $6,86 \pm 1,31$ & $6,10 \pm 3,10$ & $8,25 \pm 3,52$ \\
$\mathrm{Fe}$ & $56,67 \pm 22,29$ & $65,75 \pm 20,23$ & $77,02 \pm 17,47$ & $84,69 \pm 17,67$ \\
$\mathrm{Mn}$ & $14,77 \pm 3,55$ & $25,08 \pm 3,57$ & $35,70 \pm 8,64$ & $16,52 \pm 2,21$ \\
$\mathrm{Na}$ & $118,93 \pm 14,42$ & $133,80 \pm 26,64$ & $135,52 \pm 21,20$ & $148,39 \pm 47,73$ \\
$\mathrm{Zn}$ & $28,71 \pm 6,31$ & $42,13 \pm 6,01$ & $62,24 \pm 8,26$ & $50,68 \pm 7,12$ \\
& & \multicolumn{4}{c}{$\mathrm{g} / \mathrm{kg} \mathrm{KA} \mathrm{KA}$} \\
$\mathrm{Ca}$ & $2,25 \pm 0,40$ & $3,05 \pm 0,45$ & $3,28 \pm 0,40$ & $0,90 \pm 0,12$ \\
$\mathrm{C}$ & $422,54 \pm 11,60$ & $425,35 \pm 2,38$ & $425,86 \pm 1,87$ & $418,20 \pm 9,76$ \\
$\mathrm{Cl}$ & $6,82 \pm 0,73$ & $2,36 \pm 0,08$ & $1,20 \pm 0,15$ & $1,86 \pm 0,23$ \\
$\mathrm{~K}$ & $29,58 \pm 4,28$ & $15,18 \pm 1,77$ & $11,07 \pm 1,24$ & $18,94 \pm 2,92$ \\
$\mathrm{Mg}$ & $1,22 \pm 0,17$ & $1,24 \pm 0,19$ & $1,51 \pm 0,33$ & $1,50 \pm 0,20$ \\
$\mathrm{~N}$ & $12,73 \pm 1,16$ & $14,95 \pm 0,63$ & $16,58 \pm 0,53$ & $18,32 \pm 1,64$ \\
$\mathrm{P}$ & $0,93 \pm 0,10$ & $1,59 \pm 0,23$ & $2,25 \pm 0,61$ & $3,67 \pm 0,98$ \\
$\mathrm{~S}$ & $0,79 \pm 0,10$ & $0,97 \pm 0,13$ & $1,08 \pm 0,17$ & $1,36 \pm 0,18$ \\
$\mathrm{Si}$ & $1,45 \pm 0,29$ & $1,47 \pm 0,70$ & $1,19 \pm 0,30$ & $1,27 \pm 0,21$ \\
\hline
\end{tabular}


Taulukko 2. Kevättalvella 2009 kerätyn maissin alkuainepitoisuudet. Maissit on jaettu korjuukorkeuden mukaan neljään osaan: alin $5 \mathrm{~cm}$, seuraava $5 \mathrm{~cm}$ ja loppu verso, sekä tähkä. Tulokset ovat neljän rinnakkaisnäytteen keskiarvot \pm keskihajonta.

\begin{tabular}{ccccc}
\hline & \multicolumn{4}{c}{ Pitoisuus, mg/kg KA } \\
\cline { 2 - 5 } Alkuaine & $0-5 \mathrm{~cm}$ & $5-10 \mathrm{~cm}$ & $>10 \mathrm{~cm}$ & Tähkä \\
\hline $\mathrm{Al}$ & $344,69 \pm 124,9$ & $61,71 \pm 29,77$ & $8,23 \pm 6,16$ & $5,51 \pm 1,97$ \\
$\mathrm{Cu}$ & $5,52 \pm 1,08$ & $3,20 \pm 0,85$ & $3,48 \pm 1,89$ & $5,20 \pm 1,72$ \\
$\mathrm{Fe}$ & $481,21 \pm 187,2$ & $109,86 \pm 43,57$ & $57,06 \pm 17,11$ & $82,10 \pm 21,69$ \\
$\mathrm{Mn}$ & $13,87 \pm 4,58$ & $7,27 \pm 2,62$ & $14,74 \pm 4,40$ & $20,76 \pm 5,36$ \\
$\mathrm{Na}$ & $130,36 \pm 45,82$ & $134,58 \pm 47,93$ & $87,50 \pm 43,14$ & $72,14 \pm 41,29$ \\
$\mathrm{Zn}$ & $36,35 \pm 12,47$ & $25,68 \pm 8,74$ & $45,54 \pm 16,65$ & $70,13 \pm 17,71$ \\
\multicolumn{5}{c}{$\mathrm{g} / \mathrm{kg} \mathrm{KA}$} \\
$\mathrm{C}$ & $435,18 \pm 2,31$ & $435,30 \pm 0,87$ & $1,45 \pm 0,24$ & $1,47 \pm 0,13$ \\
$\mathrm{Ca}$ & $1,76 \pm 0,32$ & $1,24 \pm 0,23$ & - & - \\
$\mathrm{Cl}$ & $0,43 \pm 0,01$ & $0,67 \pm 0,10$ & $1,03 \pm 0,27$ & $1,48 \pm 0,38$ \\
$\mathrm{~K}$ & $0,43 \pm 0,14$ & $0,65 \pm 0,20$ & $0,93 \pm 0,26$ & $1,86 \pm 0,48$ \\
$\mathrm{Mg}$ & $0,77 \pm 0,22$ & $0,62 \pm 0,18$ & - & - \\
$\mathrm{N}$ & $9,13 \pm 0,43$ & $7,31 \pm 0,24$ & $1,25 \pm 0,24$ & $3,66 \pm 0,42$ \\
$\mathrm{P}$ & $0,90 \pm 0,16$ & $0,72 \pm 0,14$ & $0,92 \pm 0,25$ & $1,92 \pm 0,48$ \\
$\mathrm{~S}$ & $0,74 \pm 0,20$ & $0,63 \pm 0,17$ & $1,58 \pm 0,38$ & $0,680,22$ \\
$\mathrm{Si}$ & $0,71 \pm 0,19$ & $0,71 \pm 0,19$ &
\end{tabular}

Maissin eri osien tuhkapitoisuudet kuvastavat epäorgaanisten yhdisteiden kokonaispitoisuuksia biomassoissa. Mitä korkeampi alkuaineiden yhteispitoisuus on, sitä korkeampi on tuhka-ainepitoisuus (tulosta ei esitetty). Myös hampun tuhka-ainepitoisuudet kuvastavat niiden biomassojen alkuainepitoisuuksia (Kuva 1.) Tuhka-ainepitoisuudet olivat myös alhaisempia keväällä korjatussa maissi- ja hamppusadoissa. Myös kevätsadon tuhkapitoisuudet myötäilivät biomassan epäorgaanisten yhdisteiden kokonaispitoisuuksia (Tulosta ei esitetty).

Kuituhampun (USO) ja öljyhampun (Finola) kemiallinen koostumus poikkesi toisistaan huomattavasti. Öljyhampun $\mathrm{Ca}-$, Fe-, $\mathrm{Mg}-$, N-, P-, S- ja Zn-pitoisuudet olivat paljon korkeammat kuin kuituhampun vastaavat pitoisuudet (Taulukko 3). Sen sijaan alkaalimetallien ( $\mathrm{K}$ ja Na), sekä piin ( $\mathrm{Si}$ ) pitoisuudet ovat lähes samat. Ero alkuaineiden pitoisuuksissa näkyy myös tuhkapitoisuudessa, sillä Finolan tuhkapitoisuus on yli yhden prosenttiyksikön korkeampi kuin Uson biomassan tuhkapitoisuus (Kuva 1).

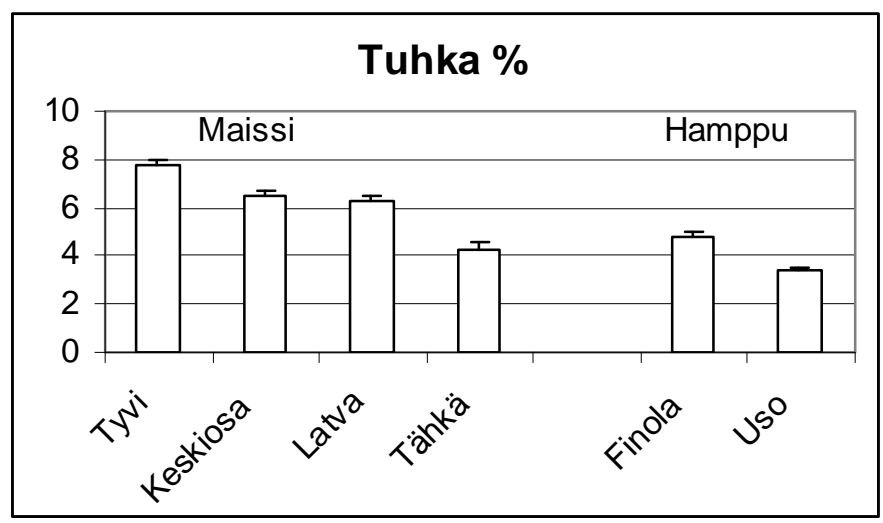

Kuva 1. Syyskuussa 2008 korjatun maissin ja kuitu- ja öljyhampun eri osien tuhkapitoisuudet prosentteina \pm s.e. 
Taulukko 3. Syyskuussa 2008 korjatun kuituhampun (USO) ja öljyhampun (Finola) biomassojen alkuainepitoisuudet. Neljän rinnakkaisnäytteen keskiarvot \pm keskihajonta.

\begin{tabular}{ccc}
\hline & \multicolumn{2}{c}{ Pitoisuus, mg/kg KA } \\
\cline { 2 - 3 } Alkuaine & Finola & Uso \\
\hline $\mathrm{Al}$ & $25,59 \pm 6,47$ & $6,54 \pm 2,58$ \\
$\mathrm{Cu}$ & $9,02 \pm 0,55$ & $4,66 \pm 0,70$ \\
$\mathrm{Fe}$ & $404,22 \pm 5,67$ & $30,44 \pm 3,67$ \\
$\mathrm{Mn}$ & $36,23 \pm 6,14$ & $21,79 \pm 2,69$ \\
$\mathrm{Na}$ & $193,67 \pm 21,23$ & $188,55 \pm 17,61$ \\
$\mathrm{Zn}$ & $82,82 \pm 2,04$ & $12,93 \pm 5,08$ \\
\multicolumn{2}{c}{$\mathrm{g} / \mathrm{kg} \mathrm{KA}$} \\
$\mathrm{C}$ & $437,42 \pm 2,02$ & $435,16 \pm 2,48$ \\
$\mathrm{Ca}$ & $14,70 \pm 2,02$ & $6,70 \pm 0,20$ \\
$\mathrm{Cl}$ & $1,96 \pm 0,08$ & $1,67 \pm 0,19$ \\
$\mathrm{~K}$ & $12,08 \pm 0,52$ & $12,05 \pm 1,08$ \\
$\mathrm{Mg}$ & $2,47 \pm 0,24$ & $1,37 \pm 0,039$ \\
$\mathrm{~N}$ & $10,30 \pm 0.40$ & $7,06 \pm 0,66$ \\
$\mathrm{P}$ & $1,01 \pm 0,12$ & $0,63 \pm 0,044$ \\
$\mathrm{~S}$ & $1,15 \pm 0,09$ & $0,63 \pm 0,06$ \\
$\mathrm{Si}$ & $1,82 \pm 0,33$ & $1,83 \pm 0,20$ \\
\hline
\end{tabular}

Taulukko 4. Alkuainepitoisuudet keväällä korjatun kuituhampun (USO) eri korjuukorkeuksissa. Neljän rinnakkaisnäytteen keskiarvot \pm keskihajonta.

\begin{tabular}{cccc}
\hline & \multicolumn{3}{c}{ Pitoisuus, $\mathrm{mg} / \mathrm{kg} \mathrm{KA}$} \\
\cline { 2 - 4 } Alkuaine & $0-5 \mathrm{~cm}$ & $5-10 \mathrm{~cm}$ & $>10 \mathrm{~cm}$ \\
\hline & & & \\
$\mathrm{Al}$ & $876,36 \pm 147,55$ & $199,45 \pm 48,04$ & $87,27 \pm 39,25$ \\
$\mathrm{Cu}$ & $7,8615 \pm 1,13$ & $5,52 \pm 1,55$ & $4,68 \pm 1,54$ \\
$\mathrm{Fe}$ & $1186,52 \pm 329,46$ & $300,08 \pm 111,03$ & $135,09 \pm 56,27$ \\
$\mathrm{Mn}$ & $23,97 \pm 6,34$ & $15,44 \pm 5,65$ & $14,66 \pm 6,17$ \\
$\mathrm{Na}$ & $131,69 \pm 35,09$ & $145,83 \pm 37,90$ & $350,50 \pm 263,05$ \\
$\mathrm{Zn}$ & $15,30 \pm 4,22$ & $9,91 \pm 2,60$ & $8,87 \pm 2,30$ \\
& & & \\
& & $\mathrm{~g} / \mathrm{kg} \mathrm{KA}$ & \\
$\mathrm{C}$ & & & \\
$\mathrm{Ca}$ & $325,36 \pm 5,40$ & $437,88 \pm 2,07$ & $439,11 \pm 2,15$ \\
$\mathrm{Cl}$ & $0,20 \pm 0,03$ & $3,67 \pm 0,40$ & $3,61 \pm 0,68$ \\
$\mathrm{~K}$ & $1,12 \pm 0,29$ & $0,17 \pm 0,018$ & $0,21 \pm 0,07$ \\
$\mathrm{Mg}$ & $0,4 \pm 0,16$ & $0,92 \pm 0,28$ & $1,20 \pm 0,65$ \\
$\mathrm{~N}$ & $6,49 \pm 0,82$ & $0,46 \pm 0,13$ & $0,481 \pm 0,14$ \\
$\mathrm{P}$ & $0,56 \pm 0,075$ & $6,03 \pm 0,33$ & $5,83 \pm 1,00$ \\
$\mathrm{~S}$ & $0,41 \pm 0,10$ & $0,46 \pm 0,12$ & $0,46 \pm 0,13$ \\
$\mathrm{Si}$ & $0,46 \pm 0,11$ & $0,38 \pm 0,10$ & $0,38 \pm 0,11$ \\
& & $0,51 \pm 0,12$ & $0,46 \pm 0,11$ \\
\hline
\end{tabular}

Eri kasvilajit ottavat eritavoin ravinteita maaperästä. Lisäksi ravinteiden saatavuus maaperässä vaihtelee maan happamuudesta ja lannoitustaseesta johtuen, minkä vuoksi biomassaksi kasvatettavan sadon alkuainepitoisuus voi vaihdella suuresti. Myös kasvien kehitysvaihe ja mahdollinen varastointi vaikuttavat biomassan kemialliseen koostumukseen (El-Nashaar ym. 2009, Christian ym. 2006). Monivuotisilla nurmikasveilla biomassa on lisäksi epähomogeenista johtuen sivuversojen kasvusta pääverson kukinnan päätyttyä. Tämän vuoksi on tärkeää määrittää tarkoitukseen kasvatettavien lajien ja lajikkeiden 
alkuainepitoisuudet eri korjuuajankohtina, jotta voidaan selvittää, mitä bioenergian tuotantomenetelmät soveltuisivat kyseisille kasvilajeille parhaiten. Tulemme keräämään näytteet tulevissa peltokokeista useammassa vaiheessa. Tulosten perusteella voidaan selvittää bioenergian raaka-aineen laadun kannalta optimaalisin keruuajankohta.

\section{Johtopäätökset}

Maissin ja hampun ja jopa eri hamppulajikkeiden (kuituhamppu ja öljyhamppu) alkuainepitoisuudet vaihtelivat huomattavasti, erityisesti termokemiallisissa bioenergian tuottomenetelmissä ongelmallisen alkalimetallin, $\mathrm{K}$ ja korroosiota aiheuttavan kloorin osalta. Lisäksi tulostemme perusteella useimpien alkuaineiden pitoisuudet olivat alentuneet huomattavasti kevätkorjuuseen mennessä, joten yksi tapa "säilöä" vankkarakenteisia bioenergiakasveja, jotka eivät lakoonnu talven aikana, on jättää sato peltoon ja siirtää korjuuajankohta kevättalveen. Syksyn aikana lisääntyvät korkeimmat Al ja Fe pitoisuudet näyttäisivät kertyvän sekä maississa että hampussa varren tyviosaan, joten niistä on mahdollista päästä eroon korjuutoimenpitein jättämällä hieman pidemmän sängen. Biologisia, käymiseen ja anaerobiseen hajotukseen perustuvia bioenergiantuottomenetelmiä varten tarvitsemme lisäinformaatiota ja biomassan liukoisten sokereiden, ligniinin ja selluloosan, sekä rasva-pitoisuuksien analysointi jatkossa on tärkeää.

\section{Kirjallisuus}

Aresta, M., Narracci, M. \& Tomassi, I. 2003. Influence of iron, nickel and cobalt on biogas production during the anaerobic fermentation of fresh residual biomass. Chem. Ecol. 19: 451-459.

Christian, D.G., Yates, N.E. \& Riche, A.B. 2006. The effect of harvest date on the yield and mineral content of Phalaris arundinacea L. (reed canary grass) genotypes screened for their potential as energy crops in southern England. J Sci Food Agric. 86: 1181-1188.

El-Nashaar, H. M., Griffith, S.M., Steiner, J.J. \& Banowetz, G.M. 2009. Mineral concentration in selected native temperate grasses with potential uses as biofuel feedstock. Bioresour Technol. 100: 35263531 .

Himken, M., Lammel, J., Neukirchen D., Czypionka-Krause, U. \& Olfs, H-W. 1997. Cultivation of Miscanthus under West European conditions: Seasonal changes in nutrient uptake and remobilization. Plant \& Soil 189: 117-126.

Jenkins, B.M., Baxter, L.L., Miles, Jr. T.R. \& Miles, T.R. 1998. Combustion properties of biomass. Fuel Process Technol. 54: 17-46.

Karp, A. \& Shield, A. 2008. Bioenergy from plants and the sustainable yield challenge, New Phytol. 178: 15-32.

Landstrom, S. Lomakka, L. \& Andersson, S. 1996. Harvest in spring improves yield and quality of reed canary grass as a bioenergy crop. Biomass and Bioenergy 11: 333-341.

Pahkala,K. \& Pihala, M. 2000. Different plant parts as raw material for fuel and pulp production. Industrial Crops and Products, 11: 119-128.

Taber, H.G., Shogren D., \& Lu, G. 2002. Extraction of silicon from plant tissue with dilute $\mathrm{HCl}$ and HF and measurement by modified inductive coupled argon plasma procedures. Commun Soil Sci Plant Anal. 33: 1661-1670.

Urban, I., Haun, E., Weicgrebe, D. \& Rosenwinkel, K.-H. 2008. The valuation of malnutrition in the mono-digestion of maize silage by anaerobic batch test. Water Science \& Technology.58: 1453-1459. 